\title{
Holocene Marine Terraces of Kunashiri Island, Kurile Islands
}

\author{
A.M.Korotky*1, N.G.Razjigaeva*1, T.A.Grebennikova*1, L.A.Ganzey*1, \\ L.M.Mokhova ${ }^{* 1}$, V.B.Bazarova ${ }^{* 1}$ and L.D.Sulerzhitsky*2
}

Low marine terrace sequence of Kunashiri Island includes Atlantic, Subboreal and Subatlantic terraces, reflected sea level oscillations during Middle-Late Holocene. The section of Atlantic terrace (5-6 m elevation) exposes storm ridge deposits, covered lacustric silts and peat. Pollen and diatom fossils and ${ }^{14} \mathrm{C}$-dates $(5,450-6,070 \mathrm{yrs} \mathrm{BP})$ correspond to development of large barrier forms with lakes in the Holocene Optimum. The paleostraits existed in the place modern Sernovodsky and Kruglovsky Isthmuses. Ocean level rose to $2.5-3 \mathrm{~m}$ a. m. s. 1 . A minor regression took place during AtlanticSubboreal cooling. Drainage of inshore zone led to development of large dunes. Subboreal deposits record two high sea level positions: about 4,010-3,400 yrs BP and 2,950-2,620 yrs BP. Small estuarian lagoons and inlets developed in that time. The cooling and ocean level lowering at Subboreal-Subatlantic boundary accompanied by formation of dune fields and swamping of the lagoon coasts $(2,220 \pm 80 \mathrm{yrs} \mathrm{BP}, 1,440 \pm$ 60 yrs BP, GIN-7895, GIN-7262). Subatlantic terrace $(2.5 \mathrm{~m})$ formed during ocean level rise to $1 \mathrm{~m}$ about $1,170-820$ yrs BP. Dunes were formed during Little Ice Age regression. The terrace study indicates their weak tectonic deformation.

Key Words : marine terrace, Holocene, Kunashiri Is., pollen, paleoenvironment, tectonic activity

\section{Introduction}

Study of marine terraces gives important information for estimation of tectonic activity of the area, natural environment development, landscape changes and sea level oscillations in the Pleistocene. There are well pronounced marine terraces sequence (to $300 \mathrm{~m}$ elevation) in the Kurile Islands (Pryalukhina, 1964; Kulakov, 1973; Melekestsev et al., 1974). Terrace deposits were almost have not been studied. There are some works, considering the age of terraces, dated by ${ }^{14} \mathrm{C}$ and $\mathrm{TL}$ without bio- and tephrostratigraphy data (Polunin, 1969; Bulgakov, 1993, 1994). This paper deal with the age, pollen and diatoms records and facies of low marine terraces of Kunashiri Island (Fig. 1) for environmental and paleolandscape reconstruction and estimation of tectonic activity.

\section{Marine Terrace Sequence}

Marine terrace (elevation to $2.5-3 \mathrm{~m}$ ) is widespreaded on the island. It consists of sand, supplied from Middle Holocene marine terraces and dunes. Modern abrasion processes are not active and abrasion material occurs only near capes. The terrace is leant to ancient abrasion-denudation cliffs or to Middle Holocene marine terraces. The elevation of the terrace increases in north part of the inlets due to SE storms. The hight of low marine terraces can not be used for correlation. It is determined by hydrodynamic conditions. For example, there is modern accumulative form ( $4 \mathrm{~m}$ elevation) on Okhotsk Sea coast, leant to Subboreal terrace. ${ }^{14} \mathrm{C}$-dating of the board with hammered nail shows modern age of

Received June 1, 1995. Accepted July 22, 1995.

*1 Pacific Institute of Geography, Far East Branch of Russia Academy of Sciences. Vladivostok, Russia.

*2 Geological Institute, Russian Academy of Sciences. Moscow, Russia. 




Fig. 1 Outline map of the studied area

deposits (GIN-7888). These terrace was formed due to storm-induced surge, that filled up the stream mouth by sandy material. Possibly, it was formed in 1890 (the year with anomaly low temperature and great storms) (Sakaguchi, 1983).

Ash-layers are more reliable mark for terrace correlation. ${ }^{14} \mathrm{C}$-date of shells from the terrace with two ash-layers (South Kurile Inlet) $820 \pm 80$ yrs BP (GIN-7903)(Table 1) shows, that the terrace was formed during Subatlantic transgression (Taira, 1980b; Korotky and Khudyakov, 1990) and corresponds to warm climatic stage Nara-Heian-Kamakura of Ja- pan Islands (Sakaguchi, 1983). Ash-layers are correlated with ash $\mathrm{Ma}-\mathrm{a}, \mathrm{Ma}-\mathrm{b}$ of Mashu Volcano (Arai et al., 1986).

Marine terrace (elevation of $3-4 \mathrm{~m}$ ) is leant to 5-6 $\mathrm{m}$ terrace and dune field in large inlets (Golovnina, Pervukhina Inlets). It is represented by storm ridges, leant to Atlantic lacustric deposits within small inlets (Kosmodemianskaya Inlet) and river mouths (Lesnaya River) (Fig. 2). This terrace occupies almost all Sernovodsky Isthmus and coastal plain in island south. The terrace is composed of eroded dunes sand, formed at Atlantic-Subboreal boundary. Pebble composition of Subboreal storm ridges indicate, that the active abrasion took place in this time. ${ }^{14} \mathrm{C}$-dates of shells from the terrace 2,620 \pm 90 yrs BP (GIN-7892), 2,950 \pm 100 yrs BP (GIN-7875) conform to second warming of Subboreal (Sakaguchi, 1983; Korotky and Khudyakov, 1990).

Well-rounded pumice, covered the storm ridges tops, is marker for this age. Thick pumice layer covers lagoon terrace near Golovnino (Fig. 1). Size of pumice is coarser in Pacific coast ( $\leqq 20 \mathrm{~cm}$. in Golovnina Inlet) compared to Okhotsk Sea coast $(3-4 \mathrm{~cm}$. in Pervukhina Inlet). Supposedly, the pumice was the product of Komagatake Volcano eruption (SE Hokkaido), that took place about 3,000 yrs BP, index Ko-f (Taira, 1980a; Arai et al., 1986). Pumice sands of the same age were found in Tokoro Plain, Eastern Hokkaido (Sakaguchi et al., 1985).

Marsh deposits (dark-brown peaty sands with vertical-oriented concretions of $\mathrm{Fe}$ hydroxides at plant remains) expose within backshore of the terrace and between storm ridges. The terrace is overlied by dunes (to 4-5 m elevation) of two generations, formed during Little Ice Age and Early Subatlantic cooling. The dunes are correlated with Little Ice Age (Kurosuna bed $\mathrm{K}_{4}$ ) and Kofun Cold Stage dunes (Kuro-suna bed $\mathrm{K}_{3}$ ) of Japan Islands (Taira, 1980a; Sakaguchi, 1983).

The terrace section, located in South Kurile Inlet, exposes (section 9-93, from top to bottom) : 
Table 1 Radiocarbon dates of Holocene deposits of Kunashiri Island

\begin{tabular}{|c|c|c|c|c|c|c|}
\hline N sample & Location & Geomorphology & Interval, $\mathrm{m}$ & Material & ${ }^{14} \mathrm{C}$-date & Labor. N \\
\hline $\mathrm{I} / 5732$ & Sernovodsky Isthmus & $4 \mathrm{~m}$ terrace & $0.45-0.50$ & peat & $2220 \pm 80$ & 7895 \\
\hline $1 \mathrm{a} / 18-93$ & Lesnaya River Mouth & $5-6 \mathrm{~m}$ terrace & $1.82-1.85$ & peat & $4310 \pm 70$ & 7876 \\
\hline $\mathrm{I} / 18-93$ & & & $1.6-1.7$ & peaty silt & $6070 \pm 70$ & 7877 \\
\hline II/18-93 & & & $1.4-1.6$ & peaty silt & $5890 \pm 130$ & 7878 \\
\hline $\mathrm{III} / 18-93$ & & & $1.0-1.2$ & peaty silt & $5450 \pm 150$ & 7879 \\
\hline IV/18-93 & & & $0.4-0.56$ & peaty silt & $4100 \pm 80$ & 7871 \\
\hline $\mathrm{V} / 18-93$ & & & $0.2-0.4$ & peaty silt & $4010 \pm 70$ & 7880 \\
\hline $3 / 13 / 93$ & Pervukhina Inlet & $12 \mathrm{~m}$ dune & $3.0-3.40$ & soil & $290 \pm 60$ & 7870 \\
\hline $5 / 13 / 93$ & & & $3.75-3.90$ & soil & $1260 \pm 90$ & 7871 \\
\hline $7 / 13 / 93$ & & & $4.60-4.65$ & soil & $860 \pm 140$ & 7872 \\
\hline $\mathrm{I} / 5687$ & & $4 \mathrm{~m}$ terrace & $2.0-2.10$ & wood & modern & 7888 \\
\hline $4 / 9 / 93$ & South Kurile Inlet & 3-4 m terrace & $0.3-0.4$ & peat & $510 \pm 50$ & 7873 \\
\hline $6 / 9 / 93$ & & & $0.5-0.6$ & peaty silt & $1770 \pm 40$ & 7874 \\
\hline $\mathrm{I} / 5697$ & & $2 \mathrm{~m}$ terrace & $0.4-0.5$ & shells & $820 \pm 80$ & 7903à \\
\hline $\mathrm{I} / 5676$ & Golovnina Inlet & $20 \mathrm{~m}$ dune & $1.7-1.95$ & soil & $190 \pm 40$ & 7886 \\
\hline $\mathrm{I} / 5778$ & & & $2.5-2.62$ & soil & $1460 \pm 50$ & 7898 \\
\hline $\mathrm{II} / 5676$ & & & $3.8-3.95$ & soil & $2130 \pm 50$ & 7887 \\
\hline $1 / 5675$ & & $12 \mathrm{~m}$ dune & $3.75-3.78$ & coal & $3840 \pm 100$ & 7885 \\
\hline $\mathrm{I} / 5674$ & & $8 \mathrm{~m}$ dune & $2.8-2.9$ & peaty sand & $1310 \pm 80$ & 7884 \\
\hline $7 / 3 / 93$ & & $3-4 \mathrm{~m}$ terrace & $0.10-0.20$ & shells & $2950 \pm 100$ & 7875 \\
\hline$I / 5706$ & Kosmodemianskaya & $5-6 m$ terace & $4.3-4.4$ & peat & $4570 \pm 70$ & 7889 \\
\hline II $/ 5706$ & Inlet & & $5.5-5.7$ & peat & $5750 \pm 70$ & 7891 \\
\hline $\mathrm{I} / 5777$ & & & $4.95-5.0$ & wood & $5920 \pm 50$ & 7898 \\
\hline $\mathrm{I} / 5708$ & & $4 \mathrm{~m}$ terrace & $2.0-2.10$ & shells & $2620 \pm 90$ & 7892 \\
\hline
\end{tabular}

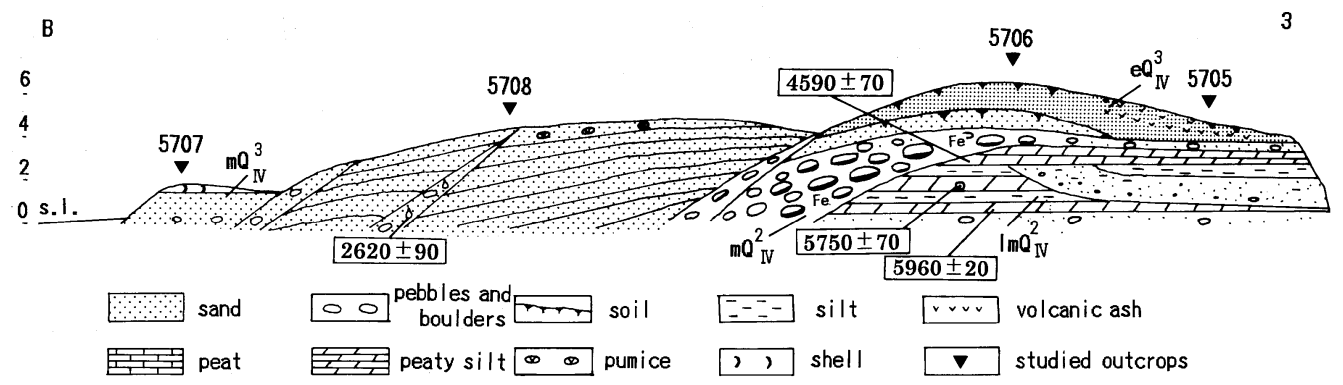

Fig. 2 Geological section of $5-6 \mathrm{~m}$ marine terraces of Kosmodemianskaya Inlet Horizontal scale is free.

Thickness, $\mathrm{m}$

1. Peat with ash-layer in the bed $\cdots \cdots \cdot 0.45$

2. Peaty silt with fine sand and

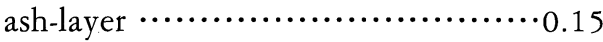

3. Grey fine well-sorting sand $\cdots \cdots \cdots \cdot 0.40$

4. Grey moderately-sorting sand

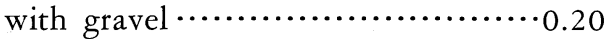

5. Grey well-sorting silty sand $\cdots \cdots \cdots \cdots, 0.20$

Three units were recognised (Fig. 3). Lower unit $(0.6-1.2 \mathrm{~m})$ contains marine diatom assemblage with predominance of sublittoral north-boreal Paralia sulcata $\leqq 90 \%$. South-boreal species are represented mainly by neritic Acti- nocyclus octonarius $\leqq 8 \%, \quad$ Actinoptychus senarius $\leqq 1 \%$ and sublittoral Hyalodiscus obsoletus $\leqq 2$ $\%$, Navicula marina $\leqq 4 \%$ and Delphineis surirella $\leqq 7 \%$. Diatom assemblage reflects shallow bay environment with sand floor and climatic condition similar to modern one (Jouze, 1962). Presence of fresh-water species, typical for flowing environments, Tabellaria flocculosa, T. fenestrara, Stephanodiscus astrea, indicates river flow to the bay.

Second unit, represented by peaty silt (0.5$0.6 \mathrm{~m}$ ), contains mainly fresh-water Frustulia rhomboides ( $\leqq 56 \%)$, typical for swamps. 


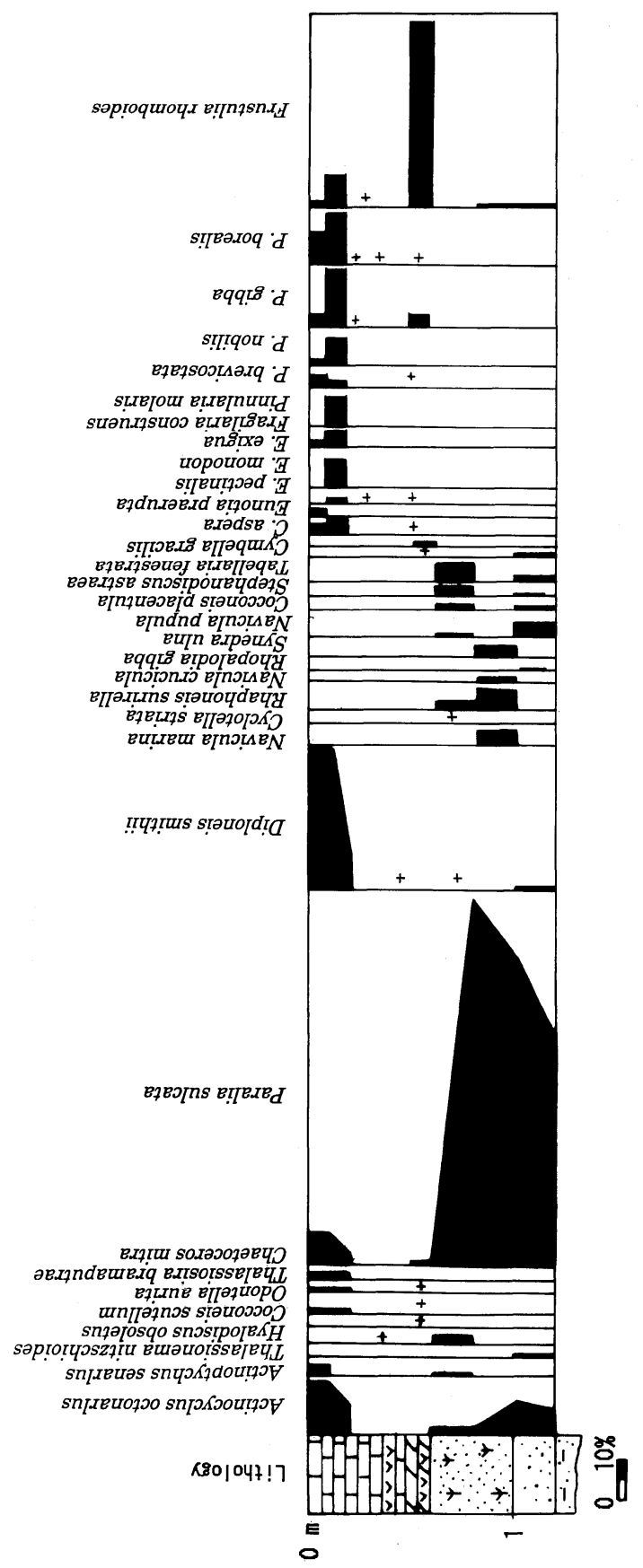

Fig. 3 Diatom assemblages of $3-4 \mathrm{~m}$ marine terrace (N 9-93), South-Kuril Inlet

Upper unit is composed of peat with ash $(0.2-0.5 \mathrm{~m})$, containing rare diatoms of different ecology, and peat $(0-0.2 \mathrm{~m})$ with marine and fresh-water diatoms. Marine species are represented by sublittoral northboreal Paralia sulcata $\leqq 10 \%$, Diploneis smitbii $\leqq 35 \%$ and neritic south-boreal Actinocyclus octonarius $\leqq 13 \%$ and Actinoptychus senarius $\leqq 3$ $\%$. Fresh-water species include coldwater Pinnularia molaris $\leqq 7 \%, P$. brevicostata $\leqq 2 \%$, P. nobilis $\leqq 7 \%$, P. borealis $\leqq 13 \%$ and moderately-warm $P$. gibba $\leqq 15 \%$. Marine species brought to the terrace surface by swamping during storms.

First unit was formed during second warming of Subboreal, peat-during Subatlantic. ${ }^{14} \mathrm{C}$-date from peaty silt with ash-layer $1,770 \pm$ 40 yrs BP (GIN-7874) (Table 1) shows that the ash is correlated with ash-layer $\mathrm{Ma}-\mathrm{d}$ of Mashu Volcano, dated about 1,700-1,850 yrs $\mathrm{BP}$, and ash-layer Tokoro II of Eastern Hokkaido coast (Taira, 1980b; Sakagushi et al., 1985). ${ }^{14} \mathrm{C}$-date from peat above upper ash-layer 510 50 yrs BP (GIN-7873) allows to correlate it with ash-layer $\mathrm{Ma}-\mathrm{b}$ of Mashu Volcano.

Peat units are characterized by tree pollen zones (Fig. 4). Palynozone Picea-AbiesBetula was obtained from peaty silt (unit 2). Conifers (Abies 22.5-40\%, Picea sect. Omorica 25.3-26.2\%, P. sect. Eupicea 13.8-22.7\% and Pinus n/p Haploxylon 2.7-3.6\%) are dominant. Fine-leaved trees pollen appear (Betula sect. Albae 2.7-5.1\%, B. sect. Costatae 18.5\%, B. exilis 1.3-7.6\% and Alnus 2.5\%). Pollen of Corylus (4\%) and Syringa (1.3\%) are found in the base.

Among herbs Compositae, Artemisia and Sanguisorba are widespread.

Second zone from peat base is composed of abundant Myrica (46.8\%), and birch pollen (Betula sect. Costatae $8.2 \%$, Betula sp. $15.2 \%$ and B. exilis 14.9\%). Conifers decrease (Abies 5.5 $\%$, Picea sect. Omorica 5.8\%). The assemblage reflects wet environments and development of birch-shrub vegetation on drainage coast. The peat was formed during Subatlantic cooling, corresponding to Kofun cold stage of Japan Islands (Sakaguchi, 1983).

Coniferous pollen increase in peat top (0$0.3 \mathrm{~m})$ : Abies $12.8-16.4 \%$, Picea sect. Omorica $18.9-32.2 \%$, P. sect. Eupicea 5.9-9.8\% and Pinus n/p Haploxylon 1.5-2.2\%. Among fineleaved tree pollen, birch are dominant (Betula 

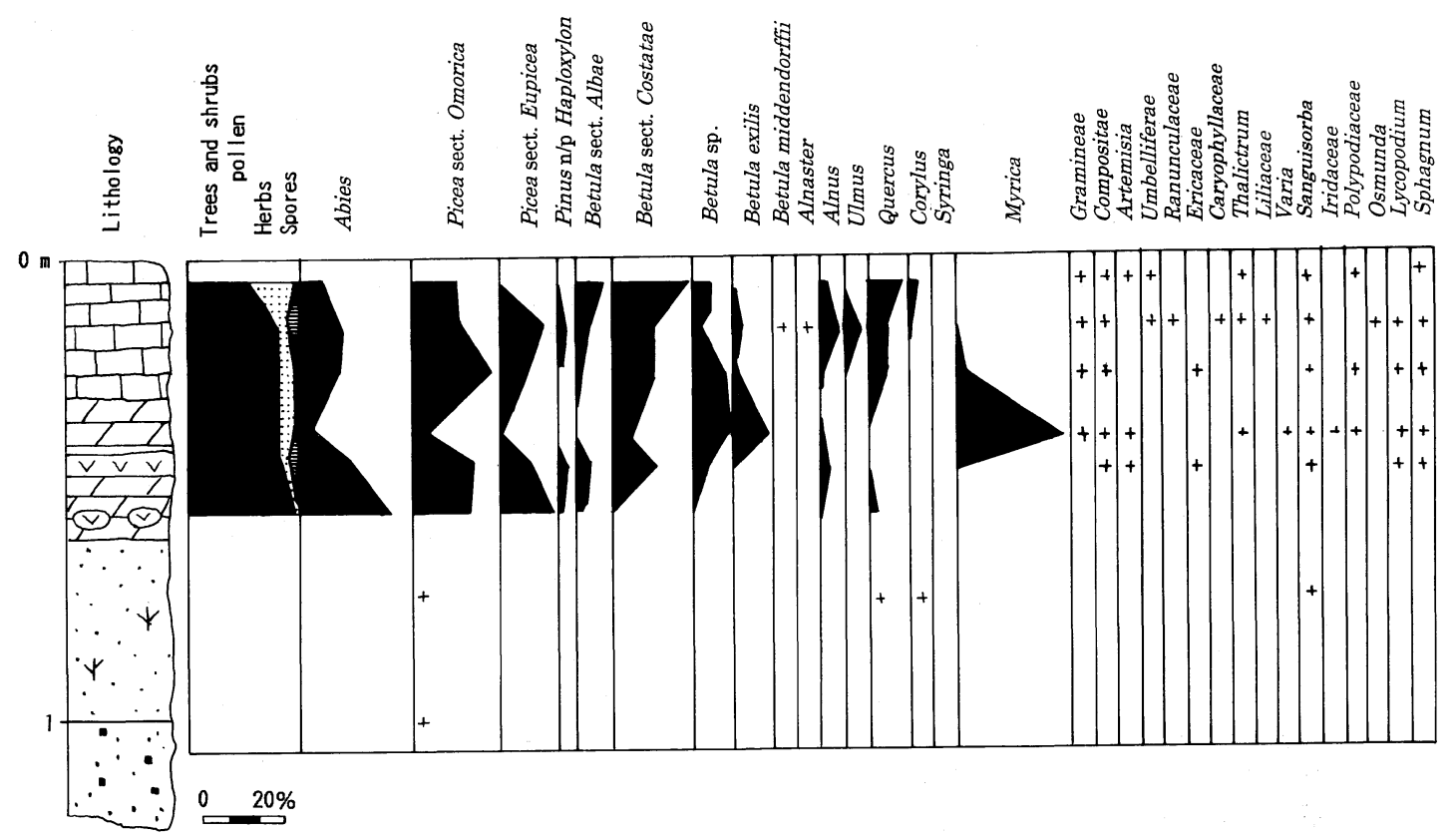

Fig. 4 Pollen diagram of $3-4 \mathrm{~m}$ marine terrace (N 9-93), South-Kuril Inlet

sect. Costatae 17.9-18.3\%, B. sect. Albae 2.65\%, B. exilis $2.5-12.8 \%$ and $B$. middendorffi 2$3.2 \%)$, Alnus (1.8-6.3\%), Alnaster (0.9\%) and Myrica (3.6\%), appear. Broad-leaved trees are represented by Quercus (7.3\%), Ulmus (6.6\%) and Corylus $(0.3-0.9 \%)$. The assemblage reflects moderately warm condition and progress cooling. Dark-coniferous forests with birch, some broad-leaved trees and swamps developed in the isthmus. Among herb



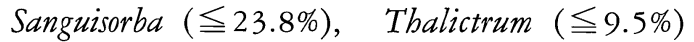
and Umbelliferae (7.1\%) dominate. Sphagnum is dominant among spores (71.4\%).

The terrace section was studied in Sernovodsky Isthmus, section 5732 (from top to bottom) :

\section{Thickness, $\mathrm{m}$}

1. Derno-soil with sand $\cdots \cdots \cdots \cdots \cdots \cdots \cdots \cdots \cdot 0.15$

2. Dark-grey, peaty sand $\cdots \cdots \cdots \cdots \cdots \cdot 0.15$

3. Peat with ironing ash-layer $\cdots \cdots \cdots \cdot 0.40$

4. Blue-grey, different-size, poorsorting sand with abundance of pumice and water plant $\cdots \cdots \cdots \cdot 0.25$

5. Grey coarser silty sand with small pumice $\cdots \cdots \cdots \cdots \cdots \cdots \cdots \cdots \cdots \cdots \cdot 0.15$

The deposits are divided into two units.
Lower unit $(0.6-1.4 \mathrm{~m})$ contains rich marine diatom complex (Fig. 5). Boreal neritic Odontella aurita $\leqq 7 \%$, Rbabdonema arcuatum $\leqq 2 \%$ and sublittoral Cocconeis scutellum $\leqq 8 \%$, Paralia sulcata $\leqq 8 \%$, Delphineis surirella $\leqq 16 \%$ and Trachyneis aspera $\leqq 2 \%$ are dominant in the base $\left(1.0^{-}-1.4 \mathrm{~m}\right)$, whereas in the top-south-boreal neritic Actinocyclus octonarius $\leqq 18 \%$, Actinoptychus senarius $\leqq 3 \%$ and some oceanic Coscinodiscus perforatus and $C$. oculus-iridis. Brackish Amphora proteus, Melosira juergensii, Navicula tuscula, N. peregrina and fresh-water, typical for flowing regime, Achnanthes lanceolata $\leqq 18 \%$, Fragilaria construens var. subsalina $\leqq 30 \%, F$. construens var. venter $\leqq 27 \%$, Opephora martyi $\leqq$ $10 \%$ and Stephanodiscus astraea $\leqq 13 \%$ appear. Diatom assemblage indicates warm condition, high sea level in this period and existence of shallow open bay near river mouth. ${ }^{14} \mathrm{C}$-date from overlaid peat 2,220 480 yrs BP (GIN7895) allows to relate formation of the unit to second warming of Subboreal. The pumice is correlated with Komagatake Volcano product Ko-f of Hokkaido Island, erupted about 3,000yrs BP (Taira, 1980b; Arai et al., 1986; Machida and Arai, 1992). Clay minerals from marine deposits entail smectite (41\%), 


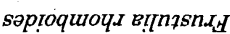

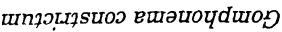

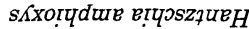

E7EInUELS ExTSOJEIn s!I Bo.xoq $\cdot d$ stptats d E7EzSOJLA2.Iq $\cdot d$ StI!ITou $d$

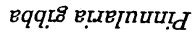



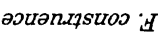

גә7นวA 'A

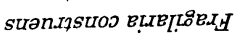

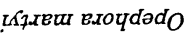

eutjesqns 'A

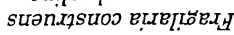

SIIEAO E.xOYdurF

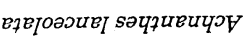
eut.xรว.xәd $N$ e.suorqo $\mathrm{N}$ e7euturnoe $N$ EIndnd BInots $N$ !Isuә8.xวก E.xIsoloW snojoxd $\mathrm{H}$

вn8Ixว e.xoydut R7EnJie eIpoledoyy euretuueun qus stauoIeD हाIगxLIns stauoqdeपy

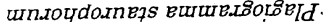

sn7ajosqo snostpole $\Lambda_{H}$ uoqenoxe eurouopqeYय E7EOInS EITEXEd
eqLIne EIJjuop eqLine EIIว̈uopO IIY7Ius s!วuoldia

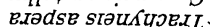

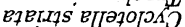
snpunगasqns so.дวоравนD

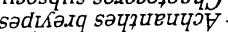
aE.IfndeUtexq iL हอเมานวอxว

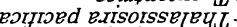

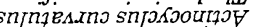
saptory

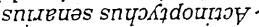

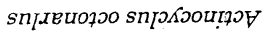
stplat-snjnoo: snzexoj.xəd sniostpoutosoว $880104+17$

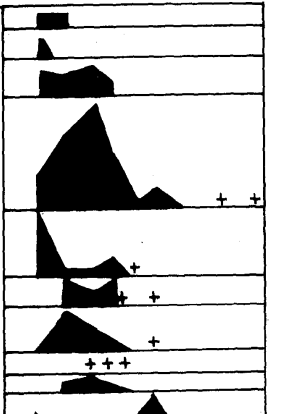

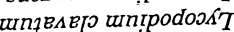
epunuso

әвәэв!podאIо

әвәэвгродоиәч วЕวगE[กAIOAUOD aвวoвsoy

วвәวв8в.มIXES วвวัว II วЕวगอวเม

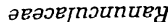
uo7a8oute7od

equosinsures

әв.хәร!IIәqس EISIUसว.रF

aอ7!sodtuo

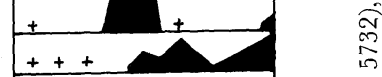

$+++2$

$z$
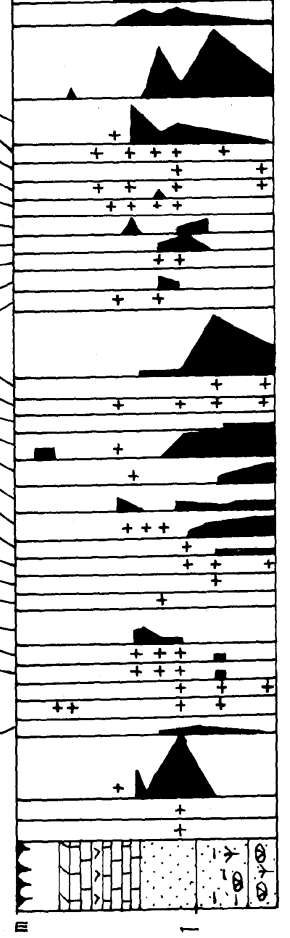

вotrouto '70әs eaว!d - ds eInjag aeqIy "zoas e[nzag

uorरXoldeH d/u snut.d

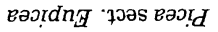

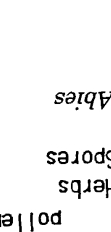

sqndys pue saad 1

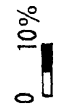

$6801047 ! 7$

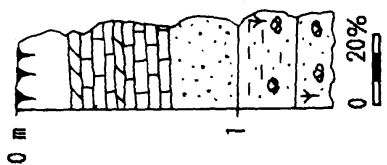



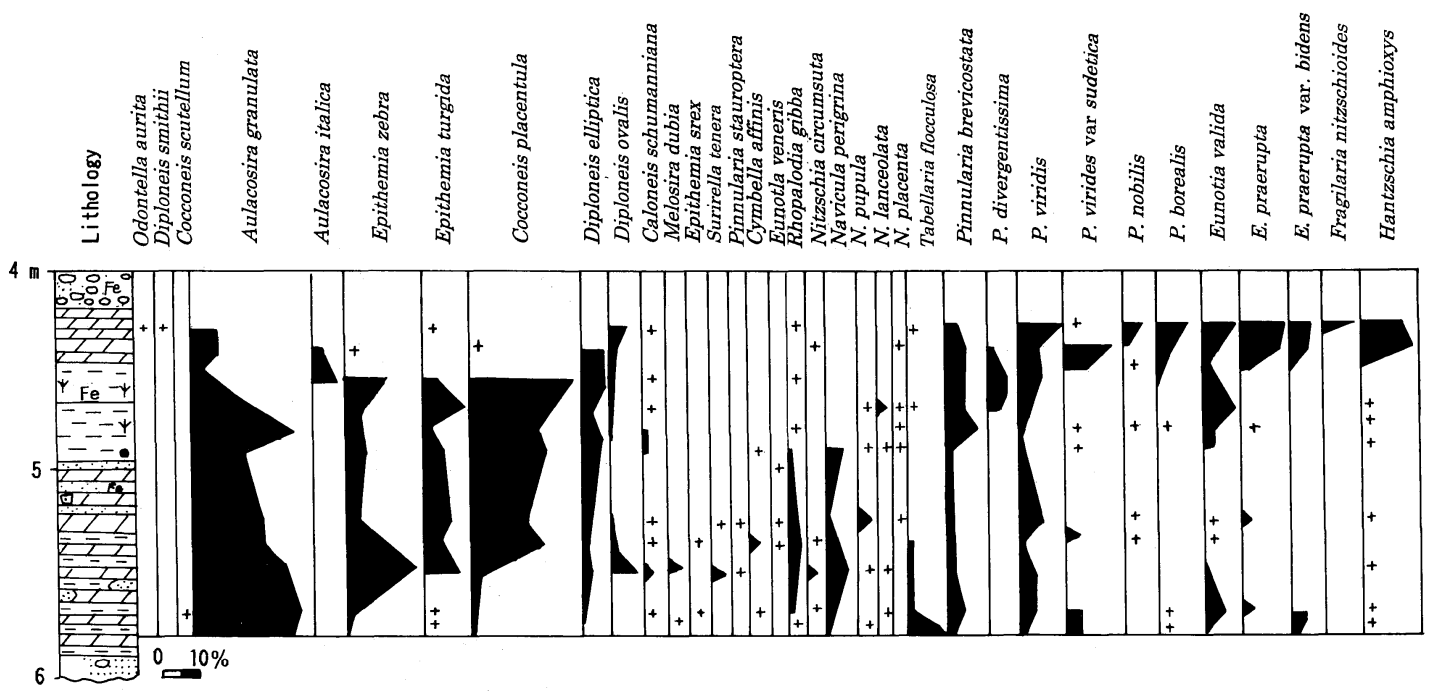

Fig. 7 Diatom assemblages of $5-6 \mathrm{~m}$ marine terrace (N 5706), Kosmodemianskaya Inlet

illite (35\%), kaolinite with chlorite (24\%).

The main source was surface wash.

Upper peat unit $(0.1-0.6 \mathrm{~m})$ contains freshwater cold diatom complex, typical for sublittoral lake zone. Aulacosira granulata $\leqq 30 \%$, Stephanodiscus astraea $\leqq 8 \%$. Pinnularia gibba $\leqq 3 \%, P$. brevicostata $\leqq 12 \%, P$. viridis $\leqq 7 \%, P$. borealis $\leqq 18 \%$ and Hantzschia amphioxys $\leqq 9 \%$ are dominant. Reobiont Ceratoneis arcus $\leqq 5 \%$ reflects river influence on lacustric flora. The unit was formed during Subatlantic $\left({ }^{14} \mathrm{C}\right.$-date $2,220 \pm 80$ yrs BP, GIN-7895). Ash-layer is correlated with ash $\mathrm{Ma}^{-} \mathrm{d}$ of Mashu Volcano.

Three pollen assemblages were obtained (Fig. 6). Marine unit contains both conifers (Abies $\leqq 42.3 \%$ and Picea sect. Omorica $\leqq 23.5$ $\%)$ and broad-leaved tree pollen (Quercus 13.2$18.8 \%$, Juglans $2.8-3.8 \%$, Tilia $1.9 \%$, Corylus 2.6\% and Phellodendron). Alnus (10.8-13.6\%) and Salix $(\leqq 2.6 \%)$ appear. The assemblage reflects development of mixed coniferousbroad-leaved forests and alder groves on the coasts and coniferous forests on the mountains. The relationship between Abies and Picea is Abies>Picea, that indicates climate warmer than the present, correlated with Yayoi warm stage (Sakaguchi, 1983 ; Sakaguchi and Okumura, 1986).

Second assemblage $(0.3-0.55 \mathrm{~m})$ differs by high spore contents $(\leqq 69.1 \%)$, tree pollen range from 30.1 to $41.1 \%$. Among spores, Polypodiaceae is dominant ( $\leqq 99.7 \%)$, in the base-Sphagnum (92.6\%). Among tree pollen, conifers (Abies 23.7-38.6\%, Picea sect. Omorica $\leqq 52.3 \%$, P. sect. Eupicea $\leqq 11.8 \%$ and Pinus $\mathrm{n} / \mathrm{p}$ Haploxylon to $5.4 \%$ ) are dominant. Birch (Betula sect. Costatae 8.0\%, Betula sp. 1.5\%, B. exilis 2.3-5.2\%), Alnus (4.3\%) and Alnaster (3.2\%) appear. Broad-leaved trees are represented by Quercus (7.1-11.7\%). Among herbs, Gramineae ( $\leqq 36.6 \%)$, Compositae (7.3\%),

Artemisia, Ranunculaceae (11\%) and Sanguisorba (25.6\%) predominate. The assemblage corresponds to Picea-Abies-Quercus zone.

Increasing of fir, shrub birch and Alnaster pollen from peat, overlaid ash-layer, reflects cooling about $1,700-1,850$ yrs BP. Increasing of Abies and Quercus pollen in upper part of the peat reflects Subatlantic warming, correlated with Nara-Heian-Kamakura warm stage of Japan Islands (Sakaguchi, 1983; Private Communication from Sakaguchi and Olsen).

Third pollen assemblage from peat top corresponds to Picea-Abies pollen zone. Conifers (Abies 37.1\%, Picea sect. Omorica 24.7\%, P. sect. Eupicea $22.4 \%$ and Pinus n/p Haploxylon 6.5\%) are dominant. Betula sect. Costatae $2.4 \%$, Betula sp. $1.8 \%$, B.exilis $1.4 \%$, Alnus (2.4\%) and Salix (1.8\%) are present. 

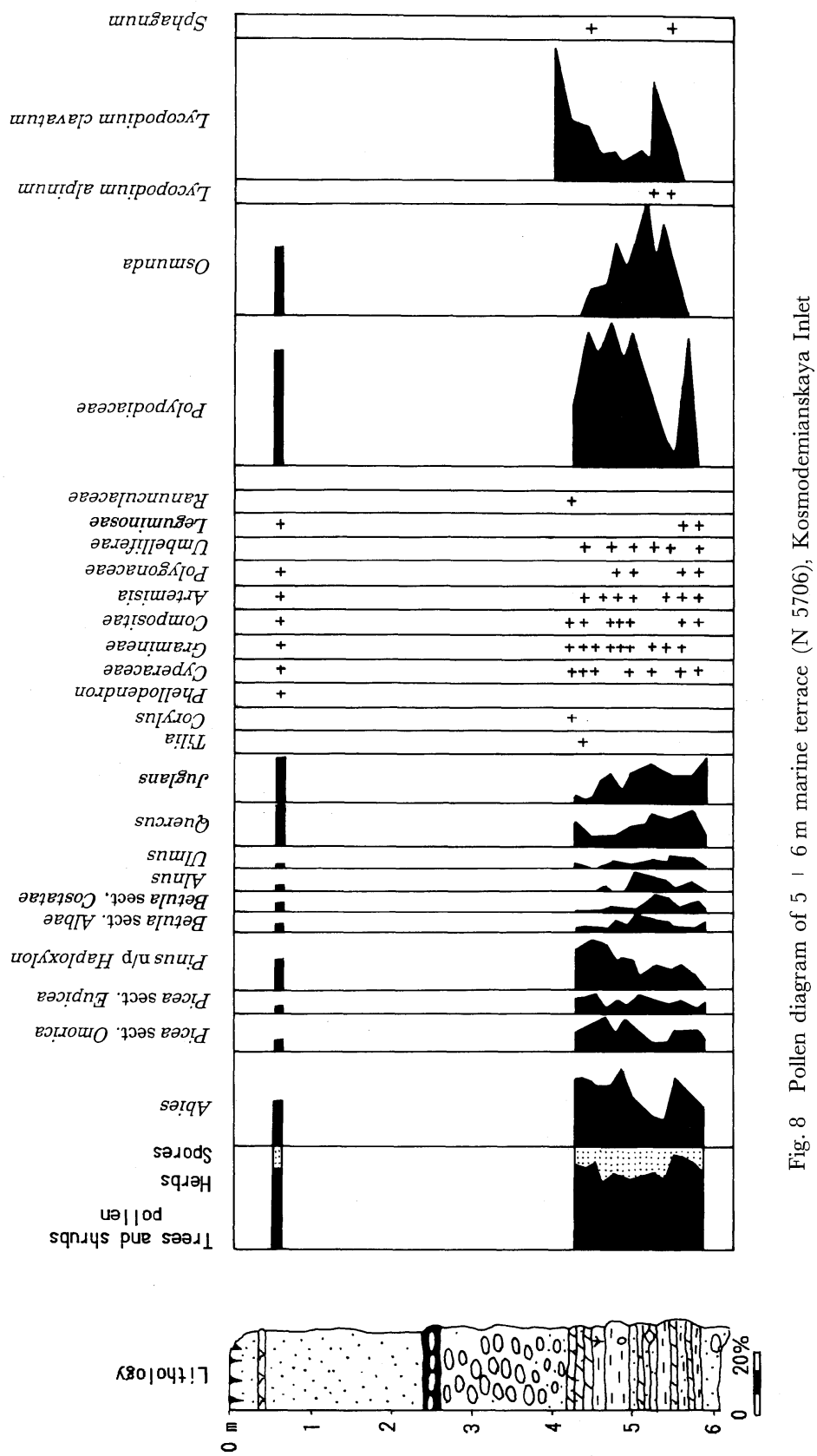
The assemblage reflects development of darkconiferous forests with birches and climate similar to the present. Appearance of Potamogeton pollen $(2.9-10.7 \%)$ indicates nearness of the lake.

Marine terrace (5-6m elevation) was found in some inlets (Kosmodemianskaya, Pervukhina, Golovnina and Lesnaya River mouth). The terrace section in Kosmodemianskaya Inlet exposes storm ridges, covered lacustric deposits (Fig. 7), section 5706 (from top to bottom) :

1. Brown-grey, humus, fine, well

Thickness, m sorting sand $\cdots \cdots \cdots \cdots \cdots \cdots \cdots \cdots \cdots \cdots \cdots \cdots \cdots, 35$

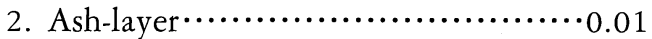

3. Dark-brown, fine, well-sorting sand, horizontal laminated $\cdots \cdots \cdots \cdots \cdot \cdots \cdot 05$

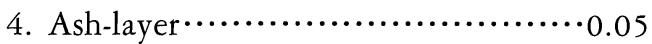

5. Grey fine well-sorting sand, horizontal laminated, with concretions at plant remains $\cdots \cdots \cdots \cdot 1.00$

6. Pebbles and boulders with ironing coarser sand $\cdots \cdots \cdots \cdots \cdots \cdots \cdots \cdot 1.80$

7. Peaty silt with thin lamina tion and sandy silt layers $\cdots \cdots \cdots \cdots \cdots \cdot 0.25$

8. Blue-grey silt with ironing spots and plant remains $\cdots \cdots \cdots \cdots \cdots \cdots \cdots, 20$

9. Dark-grey silt with black silt and grey sand layers with wood and plant remains

10. Interbedding of blue-grey sand, grey and peaty silts with coarser sand and gravel in the bed $\cdots \cdots \cdots \cdots \cdots \cdots \cdots \cdots \cdots \cdot 35$

11. Interbedding dark-grey and peaty silts with sandy lenses

12. Dark-grey coarser sand with gravel and pebbles

The section exposes eolian (layers 1 and 3), beach (layers 5 and 6), swamp (layer 7), lacustric (layers $8^{-11}$ ) and alluvial (layer 12) units.

Two diatom assemblages were divided (Fig. 7). Moderately-warm, fresh-water species occurs abundantly in lower part of the section $(4.5-5.8 \mathrm{~m})$ : Aulacosira granulata $\leqq 25 \%$, Epithemia zebra $\leqq 18 \%$, E. turgida $\leqq 10 \%$, and moderately-cold Cocconeis placentula $\leqq 25 \%$. Some brackish species (Nitzschia circumsuta $\leqq 2 \%$ and Navicula peregrina $\leqq 5 \%)$ and rare sublittoral mezogalob Cocconeis scutellum, Diploneis smithii appear too. Diatom assemblage reflects sedimentation in coastal fresh-water lake with small entering of sea waters and $\mathrm{pH}$ 5.5-6.2. The deposits were formed during Holocene Optimum, that suggested by ${ }^{14} \mathrm{C}$ dates of wood $5,920 \pm 50$ yrs BP (GIN$7898)$ and peat $5,750 \pm 70$ yrs BP (GIN7891) (Table 1), correlated to Early Jomon of Japan Islands (Sakaguchi, 1983).

Fresh-water cold Pinnularia brevicostata $\leqq 5 \%$, $P$. divergentissima $\leqq 12 \%, \quad P$. viridis $\leqq 12 \%, \quad P$. nobilis $\leqq 5 \%, \quad P$. borealis $\leqq 8 \%$, Eunotia valida $\leqq 7 \%$, E. praerupta $\leqq 11 \%$ and Hantzschia amphioxys $\leqq 12 \%$ are dominant in second assemblage $(4.3-4.5 \mathrm{~m})$, indicating swamp environment with $\partial$ Í of 4.7 . The deposits were formed during cooling and regression at Atlantic-Subboreal boundary. ${ }^{14} \mathrm{C}$-date from peat top is 4,570 770 yrs BP (GIN-7889). This regression corresponds to Kemigawa regression of Tokyo Bay, the middle Jomon minor regression and the Middle/Late Jomon cold stage (Ota et al., 1982 ; Sakaguchi, 1983; Sakaguchi et al., 1985).

Pollen of trees $(\leqq 78.6 \%)$ dominate in lacustric deposits, herb pollen is $1.5-13.5 \%$, spores $7.8^{-}$ 36.6\% (Fig. 8). Conifers (Abies 12.4-24.8\%, Picea sect. Omorica $4.1-17.5 \%$, Picea sect. Eupicea 3.6-10.8\% and Pinus n/p Haploxylon $6.7-25.7 \%)$ and broad-leaved trees pollen (Juglans 4.3-22.1\%, Quercus 7.4-19.3\%, Ulmus $\leqq 6.5 \%$, Carpinus, Corylus, Pbellodendron and Tilia) are dominant. The relationship of Abies $>$ Picea is seen throughout all samples. Contents of fine-leaved trees pollen (Betula sect. Albae $1.3-8.3 \%$, B. sect. Costatae $0.3-9.5 \%$ and Alnus $0.3-11.7 \%$ ) are low. Pollen assemblage reflects development of mixed coniferous broad-leaved forests and warmest climate during Holocene Optimum. Alnus increases in the horizon with ${ }^{14} \mathrm{C}$-date $\mathrm{GIN}-7898$, that shows weak cooling during Atlantic and small lowering of sea level, drainage of the coasts and development of Alnus groves on coastal plain.

Pollen assemblage from buried soil on the ancient storm ridge is characterised by high 

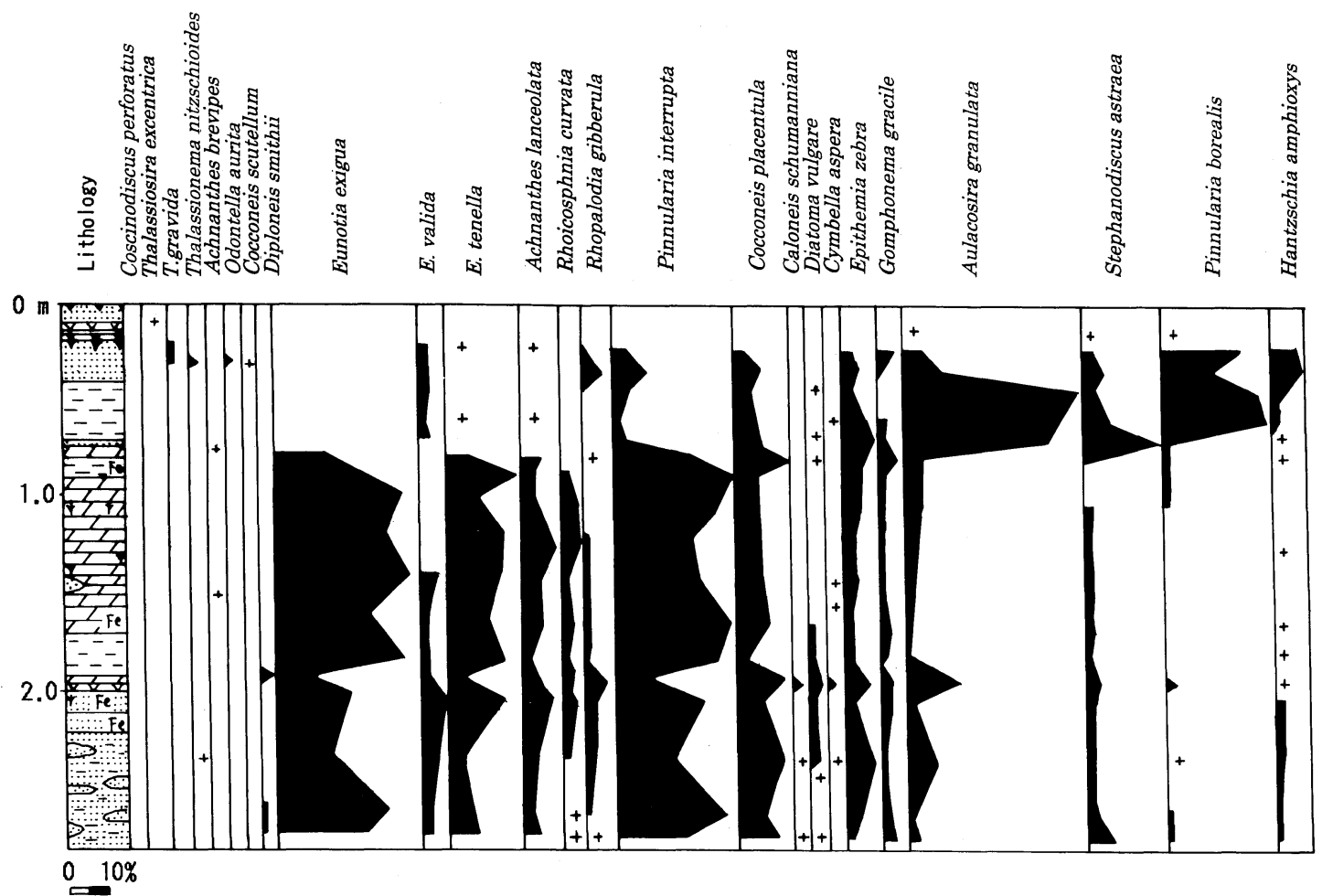

Fig. 9 Diatom assemblages of $5-6 \mathrm{~m}$ marine terrace ( $\mathrm{N}$ 5705), Kosmodemianskaya Inlet

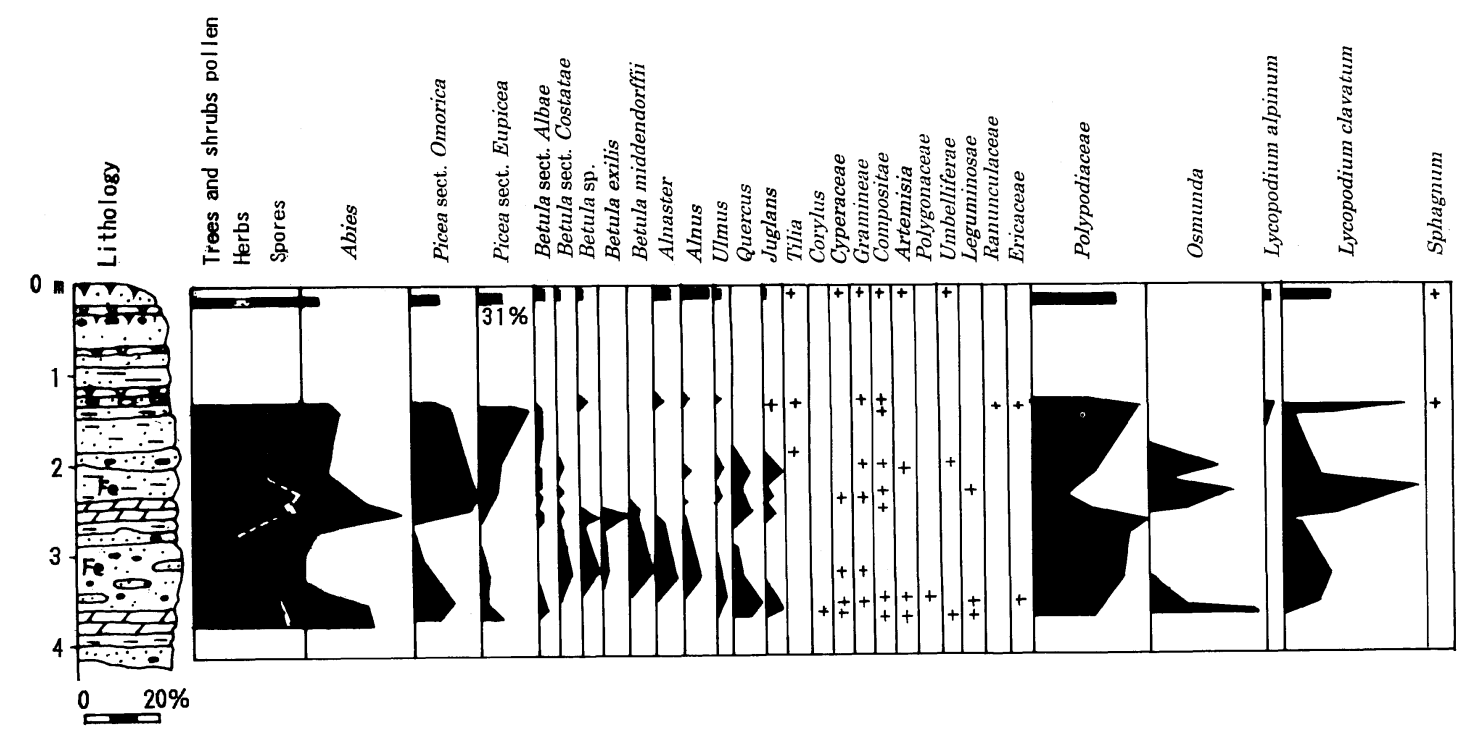

Fig. 10 Pollen diagram of $5-6 \mathrm{~m}$ marine terrace (N 5705), Kosmodemianskaya Inlet 


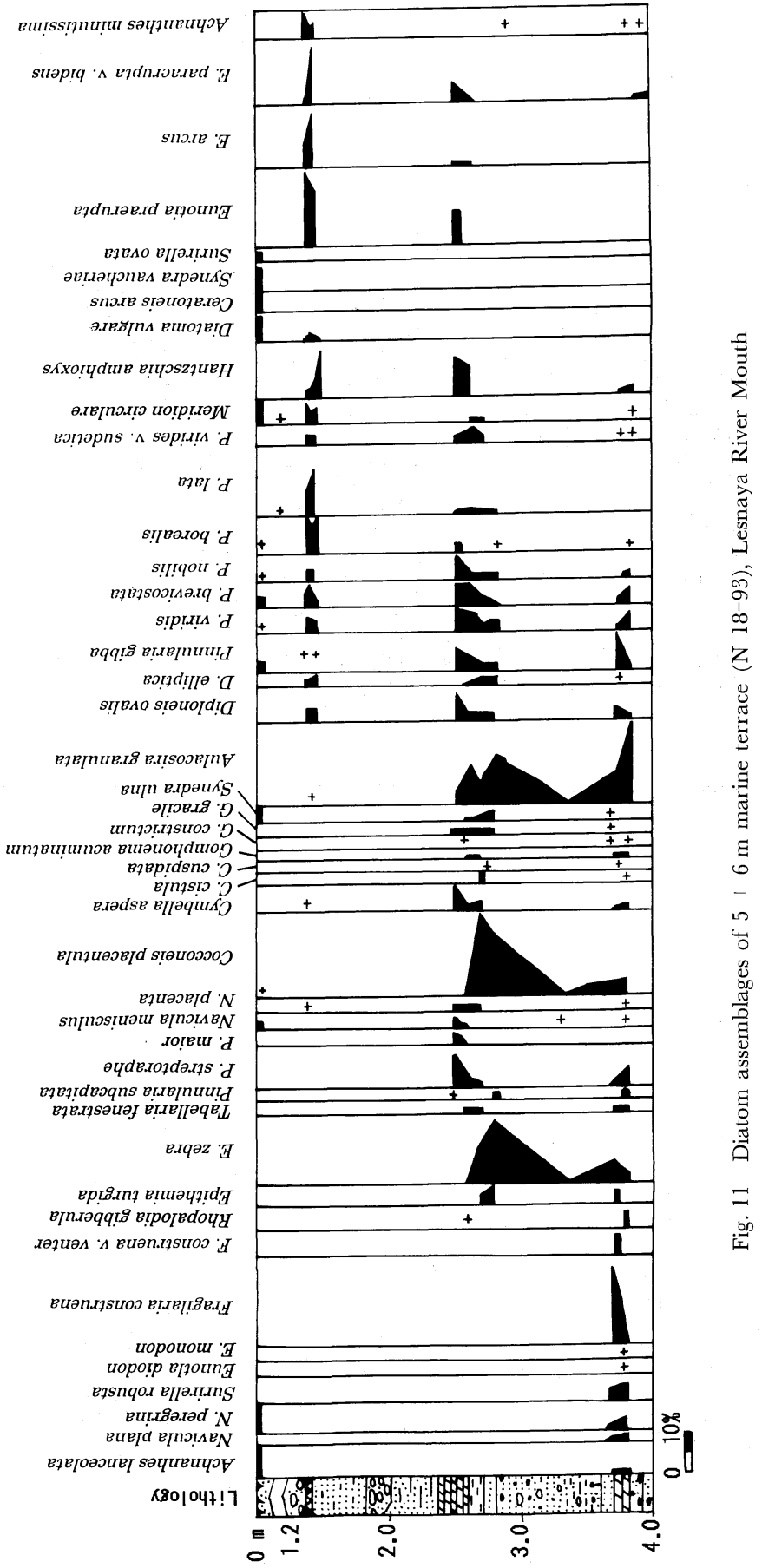


contents of broad-leaved trees pollen (Quercus 19.3\%, Juglans $22.1 \%$, Ulmus $1.7 \%$ and Phellodendron 0.6\%). Among conifers, Abies (23.5 $\%)$ predominates. The assemblage indicates vegetation of temperate zone, climate warmer than the present and corresponds to Early Subboreal warm stage, correlated to First Late Jomon warm stage (Sakaguchi, 1983).

Heavy mineral composition reflects facies changes. Ilmenite $(\leqq 72 \%)$ and pyroxenes $(\leqq 40 \%)$ are dominant in lacustric deposits. Magnetite contents are less than 3\%. They increase in top of peat, their source seems to be eolian entrance. Beach sands are characterized by the dominate of magnetite ( $\leqq 49$ $\%$ of sand and $80 \%$ of silt fractions). Pyroxenes $(\leqq 58 \%)$ and magnetite $(\leqq 30 \%)$ are main minerals of eolian sands. Leucoxene, zircon, apatite and Fe hydroxides appear in all samples, but are in small present $(\leqq 2 \%)$. Clay minerals are represented by smectite $(31-45 \%)$, illite $(28-43 \%)$ and chlorite $>$ kaolinite $(16-32 \%)$. Smectite entered due to alluvium. In modern river sediments smectite reaches to $78 \%$. Illite contents increase in peat. Zeolites appear in all section deposits.

Younger lacustric deposits are exposed in the same terrace (5705)(Fig. 2). The diatom diagram is divided into four parts (Fig. 9). Lower deposits $(3.4-3.8 \mathrm{~m})$ are characterized by diatom complex similar to Atlantic lacustric assemblage of 5706. The deposits of 2.75$3.6 \mathrm{~m}$ have some river and swamp diatoms. The deposits accumulated during Atlantic -Subboreal boundary regression. The sea level lowering led to erosion and destruction of the barrier form. The lake was drained and swamp developed. The swamp-lacustric deposits $(2.4-2.75 \mathrm{~m})$ contain cold freshwater diatoms: Aulacosira granulata $\leqq 20 \%$, Synedra ulna $\leqq 4 \%$ and sublittoral benthos Cocconeis placentula $\leqq 30 \%$, Pinnularia gibba, $P$. viridis, $P$. brevicostata, $P$. nobilis, $P$. viridis var. sudetica, Eunotia praerupta and Hantzschia ampbioxys. High contents of rheophilous species $\leqq 25 \%$ (Achnanthes lanceolata, A. lanceolata var. capitata, $A$. minutissima and Diatoma vulgare) show intensive river influence. The $\mathrm{pH}$ of the deposits is 5.1. The peat top (1.1-
$1.85 \mathrm{~m}$ ) includes cold water swamp Hantzschia amphioxys, Eunotia praerupta, E. arcus, E. praerupta var. bidens and sublithoral benthos species of Pinnularia genus. Decreasing of rheophilous species shows that there was no river influence. The $\mathrm{pH}$ of peat is 5.2-5.8.

The samples are divided into five pollen zones (Fig. 10). Pollen zone Abies-PinusQuercus-Juglans $(3.6-4.1 \mathrm{~m})$ is similar to Atlantic lacustric deposits of 5706 : tree pollen reach $\leqq 70.2-77.9 \%$, herb $\leqq 10.1 \%$, spores $\leqq$ 10.4-17.3\%. Conifers (Abies 28.2-30.4\%, Picea sect. Omorica 17.2-18\%, P. sect. Eupicea $\leqq$ $11.6 \%$ and Pinus s/p Haploxylon 16.3-26.8\%) are dominant. Broad-leaved trees (Juglans $\leqq$ $11.7 \%$, Quercus $\leqq 12 \%$, Ulmus $4.2 \%$, Corylus 0.8 $\%)$ are abundant. Fine-leaved trees are represented by Betula sect. Costatae $0.3-0.4 \%, B$. sect. Albae $1.2-4.2 \%$ and Alnus $0.9 \%$.

Pollen zone Betula-Alnaster (2.6-3.6 m) is characterised by high spore content (2560\%). Alnaster (47.7-80\%) is dominant birch pollen contents and variety increase, shrub birch appear (Betula sect. Albae $\leqq 18.2 \%$, $B$. sect. Costatae $\leqq 5.4 \%, \quad$ B. exilis $\leqq 12.5 \%$, B. Middendorffi $\leqq 10.8 \%$ and $B . \mathrm{sp} . \leqq 10.5 \%$ ). Conifers does not exceed $6 \%$. Pollen zone reflects climate cooler than the present at Atlantic-Suboreal boundary, sea level lowering and development of Alnaster groves on river valleys and coastal plain.

Pollen zone Picea-Abies-Pinus (2.05-2.6 $\mathrm{m})$ is dominated by conifers-Abies ( $\leqq 39.2 \%$ ), Picea sect. Omorica (26-29\%), P. sect. Eupicea ( $\leqq 10 \%)$, Pinus $\mathrm{n} / \mathrm{p}$ Haploxylon (18.2-36.6\%). Broad-leaved trees appear (Juglans $\leqq 11.7 \%$, Quercus $\leqq 8.4 \%$ and Ulmus $\leqq 2.1 \%)$. Apparently, pollen assemblage indicates first warm stage of Subboreal.

Pollen zone Picea-Abies-Pinus (1.1-2.05 $\mathrm{m})$ entails trees pollen $(\leqq 63 \%)$, herb $(\leqq 18 \%)$ and spores $(\leqq 44 \%)$. Among trees, conifers are dominant: Abies (6.2-17\%), Picea sect. Omorica (9-17.9\%), P. sect. Eupicea (8.4-30.7 $\%)$ and Pinus n/p Haploxylon (25-60.6\%). Fine-leaved trees are represented by Betula sect. Albae 1.2-2.7\%, B. sect. Costatae 1.2$2.7 \%$ and $B$. sp. $\leqq 2.4 \%$. Broad-leaved trees are only sporadic and few in number (Juglans 
$\leqq 1.2 \%$, Quercus $0.3 \%$, Ulmus $2.3 \%$ and Tilia $0.6 \%)$. The relationship between Abies and Picea is Abies < Picea.

Pollen zone Picea, obtained from eolian deposits, is composed mainly of Picea (Picea sect. Eupicea 39\% and P. sect. Omorica 12.9\%) accompanied by other conifers (Abies 15.5\%, and Pinus n/p Haploxylon 27.7\%) and some fine-broad trees pollen. The pollen zone indicates that the vegetation of the northern part of temperate zone and the climate been similar to the present.

Clay minerals of lacustric deposits of this section contain higher contents of illite, reaching a maximum of $54 \%$ in peat layers. Smectite contents $(\leqq 43 \%)$ increase in the units, formed under active river influence.

Ash-layers, located in eolian sands, are composed mainly by pumice colourless glass shards, clinopyroxenes $(\leqq 52.7 \%)$ and Yorthopyroxenes ( $\leqq 23.9 \%)$. They are correlated to ash-layers $\mathrm{Ma}-\mathrm{b}$ and $\mathrm{Ma}-\mathrm{d}$ of Mashu Volcano (Arai et al., 1986 ; Machida and Arai, 1992).

5-6 $\mathrm{m}$ marine terrace was studied in detail in $250 \mathrm{~m}$ from Lesnaya River mouth. The section $18^{-93}$ exposes (from top to bottom) :

Thickness, $\mathrm{m}$

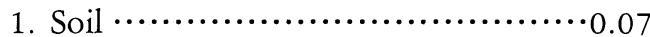

2. Interbadding of peaty silt and sand with two ash-layers $\cdots \cdots \cdots \cdots \cdot \cdots \cdot 0.13$

3. Dark-grey humus coarser sand $\cdots \cdots \cdot 0.20$

4. Dark-brown ironing silt, fine

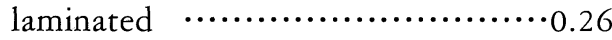

5. Grey well-sorting sand $\cdots \cdots \cdots \cdots \cdots \cdots, 0.07$

6. Dark-blue silt, fine laminated with clay layers with ironing

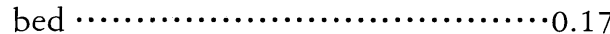

7. Peaty silt, fine laminated with vertical ironing of plant

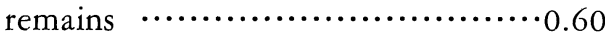

8. Pink-brown silt, fine laminated, with vertical Fe-hydroxides concretions of plant remains $\cdots \cdots \cdots \cdot \cdots \cdot 20$

9. Grey, dark-blue, grey-green silts, fine laminated with plant remains and $\mathrm{Fe}_{2} \mathrm{O}_{3}$ concretions $\cdots \cdots \cdots \cdots \cdots \cdots \cdots \cdots \cdots \cdots \cdots \cdots, 22$

10. Peaty silt
11. Ash-layer with ironing layers on the contacts $\cdots \cdots \cdots \cdots \cdots \cdots \cdots \cdots \cdots \cdots \cdots \cdot 01$

12. Grey different size sand with peaty lenses, debris, ironing spots, and plant remains $\cdots \cdots \cdots \cdots \cdot \cdots \cdot 28$

13. Light-grey, different size, silty sand, fine laminated with gravel and plant remains

Two units were divided by diatom complexes (Fig. 11). Lower unit (0.76-2.7 m) deposited in moderately-cold lake, that is suggested by rich fresh-water diatom assemblage with dominant of Eunotia exigua $\leqq 35 \%$, E.valida $\leqq 8 \%$, E. tenella $\leqq 14 \%$ and Pinnularia interrupta $\leqq$ $33 \%$. The $\mathrm{pH}$ of deposits ranges from 4.9 to 5.5 .

Upper unit $(0.2-0.76 \mathrm{~m})$ contains more coldwater diatom complex: Aulacosira granulata $\leqq 45 \%$, Pinnularia borealis $\leqq 25 \%, P$. brevicostata $\leqq 6 \%$, Eunotia praerupta $\leqq 18 \%, E$. praerupta var. bidens $\leqq 4 \%$ and Hantzschia amphioxys $\leqq 7 \%$. Moderatly-warm Stephanodiscus astraea $\leqq 20 \%$ and Rbopalodia gibberula $\leqq 5 \%$, typical for flowing waters, appear too. Diatom assemblage indicates swamping of the lake, existed to Subboreal.

Important fact is the presence of marine diatoms Cocconeis scutellum, Diploneis smithii, Thalassiosara excentrica, Thalassionema nitzschioides and Coscinodiscus perforatus in the all sections and reach a maximum in horizon $0.2-0.4 \mathrm{~m}$. Marine diatoms entered into the coastal lake during storms and indicate higher sea level position than modern.

The lake was formed in Atlantic under high sea level standing due to formation of large barrier form in river mouth. The barrier form boulder deposits are exposed down-stream. Lacustric deposits were dated by ${ }^{14} \mathrm{C}$ as $6,070 \pm 70$ yrs BP (GIN-7877), 5,890 130

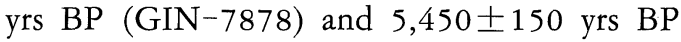
(GIN-7879) (Table 1). ${ }^{14} \mathrm{C}$-date $4,310 \pm 70$ yrs BP (GIN-7876) from peaty silt, overlaid lower ash-layer is rejuvenated. ${ }^{14} \mathrm{C}$-date from upper part are $4,100 \pm 70$ yrs BP (GIN$7871)$ and 4,010 $770 \mathrm{yrs} \mathrm{BP}(\mathrm{GIN}-7880)$ show that the lake was existed to first warm stage of Subboreal.

Five pollen assemblages were divided. The 
deposits of the base $(1.8-2.7 \mathrm{~m})$ contain mixed pollen assemblage : conifers (Abies, Picea sect. Omorica, P. sect. Eupicea, Larix and Pinus n/p Haploxylon), fine-leaved trees (Betula sect. Albae, B. sect. Costatae, B. sp., B. exilis, Alnus and Alnaster) and broad-leaved trees (Quercus, Juglans, Ulmus and Phellodendron), reflecting development of mixed forests in Atlantic.

Second pollen assemblages $(0.9-1.8 \mathrm{~m})$ are characterised by increasing of birch pollen (Betula sect. Albae and B. sect. Costatae) with conifers (Abies, Picea sect. Eupicea, P. sect. Omorica), and broad-leaved (Quercus, Phellodendron and Corylus) and some fine-leaved trees (Alnus).

In third assemblage, recorded in the top of Atlantic lacustric deposits $(0.7-0.9 \mathrm{~m})$, broadleaved trees pollen predominate (Quercus $\leqq$ $32 \%$, Juglans $9.6 \%$, Phellodendron $1 \%$ and Ulmus $1.3 \%)$, accompanied by fine-leaved trees (Betula sect. Albae 9.9\%, B. sect. Costatae 16\%, Betula sp. 4.2\%, and Alnus 19.2\%). Conifers pollen rapidly decrease (Abies 3.2\%, Picea sect. Omorica $1.9 \%$ and P. sect. Eupicea $0.3 \%$ ). The assemblage reflects development of broadleaved with birches forests on the coasts, Alnus groves in river valleys and conifers forests on the mountains. The paleovegetation was similar to present oak-birch forests of south part of the island (Grabkov et al., 1989).

Conifers, birches and Quercus are dominant in fourth pollen assemblage, obtained from Subboreal lacustric deposits $(0.2-0.7 \mathrm{~m})$. Conifers increase in the upper part. The paleoclimate in first warm stage of Subboreal was warmer than today.

Fifth pollen assemblages from top of the terrace $(0-0.2 \mathrm{~m})$ are composed mainly of conifers (Abies $\leqq 9.6 \%, \quad P$. sect. Omorica $\leqq 41.3 \%$, Picea sect. Eupicea $0.8 \%$ and Pinus n/p Haploxylon 16.5\%), accompanied by birch pollen (Betula sect. Albae and B. sect. Costatae), Alnus and Alnaster. It is suggested that the paleovegetation was similar to modern dark-conifer forests with some birches. The climate was similar to the modern. Presence of two ash-layers allows to relate the deposits to Subatlantic.

Ash-layer from lower part of the section is correlated to the $\mathrm{Ma}-\mathrm{f}$ ash of Mashu Volcano, erupted about 7,190-6,460 yrs BP (Taira, 1980b; Arai et al., 1986; Machida and Arai, 1992). Age of the ash-layer in this section was calculated about 6,420 yrs BP, assuming rate of sedimentation about $1 \mathrm{~mm} / \mathrm{y}$. The ash-layers from terrace top $(0-0.2 \mathrm{~m})$ are correlated to the $\mathrm{Ma}^{-} \mathrm{d}$ ash and the $\mathrm{Ma}-\mathrm{b}$ ash of Mashu Volcano.

Clay minerals are composed from smectite $(\leqq 78 \%)$ and kaolinite $>$ chlorite $(22-35 \%)$. Kaolinite with chlorite contents increase in the base of lacustric unit (to 55\%) and peaty silts (ฏ61\%). Apparently, kaolinization of alumino-silicates took place under influence of low temperature sulphate-waters of Lesnaya River.

Kisliy Stream from Mendeleev Volcano, flowing into Lesnaya River, has acid water ( $\mathrm{pH}$ less than 3.2). Illite appears in deposits with maximum contents of marine diatoms $(45 \%)$. Pyroxenes $(\leqq 80 \%)$ predominate in lacustric deposits, magnetite $(\leqq 22 \%)$ in the top of section.

\section{Discussion and concluding remarks}

Low marine terrace sequence of Kunashiri Island includes Atlantic, Subboreal and Subatlantic terraces, covered by dunes, reflected sea level oscillations during Middle-Late Holocene.

At the beginning of the Atlantic the landbridge between Kunashiri and Hokkaido Islands was destroyed. In this time the sea level was about $25 \mathrm{~m}$ lower than the present (Ota et al., 1982; Sakaguchi et al., 1985; Korotky and Khudyakov, 1990). Intensive rise of the sea level to $+2.5-3 \mathrm{~m}$ led to formation of the straits on the place of Sernovodsky and Kruglovsky Isthmuses. There were a large open bay on Pacific side and a large lagoon on Okhotsk Sea side of SouthKurile Isthmus. Active abrasion caused entrance of large volume of detrital material into coastal zone. Large barrier forms and separated numerous coastal lakes, were formed. Some of these lakes exist today (Aliger, Lagunnoe Lake etc.), some-only to Subboreal (paleolake near Lesnaya River mouth), someonly in Atlantic (paleolake in Kosmodemyanskaya Inlet). The section of Atlantic terrace 
(5-6 $\mathrm{m}$ elevation) was first found on the South Kurile. The sections expose storm ridge deposits, covered lacustric silts and peat. Pollen and diatom fossil and ${ }^{14} \mathrm{C}$-dates (5,450-6,070 yrs BP) correspond to Holocene Optimum. The deposits record weak cooling during Atlantic, dated about 5,750土 70 yrs $\mathrm{BP}(\mathrm{GIN}-7891)$, that correlated to small oscillation about 5,630 yrs BP of the Holocene fluctuations curve of Japan Sea level (Korotky et al., 1994). Mixed conifer-broad-leaved forests were widespreaded on the island, that shows warmer climate than the present. This warm climatic stage in Kunashiri Island is well correlated to Early Jomon warmest stage in Japan, accompanied by transgression. Possibly, the warming in Atlantic in Kunashiri Island was intensified by influence of warm marine currents at 5,900-4,700 yrs BP (Taira, 1992).

A minor regression took place during Atlantic-Subboreal cooling, correlated to Middle Jomon regression in Japan (Ota et al., 1982 ; Sakaguchi, 1983; Sakaguchi et al., 1985). Drainage of inshore zone led to development of large dunes (to $20 \mathrm{~m}$ height) due to supply of sand material from nearshore zone Narrow landbridges were formed within Sernovodsky and Kruglovsky Isthmuses. This event was dated by ${ }^{14} \mathrm{C}$ as $4,660 \pm 15$ yrs $\mathrm{BP}$ (GIN7264).

Subboreal deposits record two high sea level positions : about 4,010-3,400 yrs BP (GIN7879), 7,038 and 2,950-2,620 yrs BP (GIN7879, GIN- 7892), correspond to Late Jomon retransgression (Funabashi Transgression) of Japan Islands (Sakaguchi, 1983). The transgression led to erosion of the dunes. Large amount of sand entered into coastal zone and wide sand beaches were formed. Fragments of these accumulative forms are wide spread on the Pacific Islands. Probably, this fact explains the opinion, that the Subboreal Transgression was even larger than Atlantic Transgression (Schofield, 1964 ; Yamazaki, 1983 from Private Communication from Sakaguchi and Olsen). Small estuarian lagoons and inlets developed at that time. Coniferous forests developed on northern parts of the island, mixed coniferous with some broadleaved trees - on the central and southern coasts. The climate was warmer than the present and conforms to First and Second Late Jomon warm stages of Japan (Sakaguchi, 1983).

The cooling and ocean level lowering at Subboreal-Subatlantic boundary accompanied by formation of dune fields and swamping of the lagoon coasts $(2,220 \pm 80$ yrs BP, $1440 \pm$ 60 yrs BP(GIN-7895, GIN-7262). This dune generation is correlated to Kurosuna dune $\mathrm{K}_{3}$ of Japan. The inlets within sea side of the isthmuses were closed and reduced to the lakes. The cooling of Kunashiri Island comforms to Kofun cold stage and Nakayama Regression of Japan (Sakaguchi, 1983).

Subatlantic terrace $(2.5 \mathrm{~m})$ formed during ocean level rise (to $1 \mathrm{~m}$ ) about $1,170-820 \mathrm{yrs}$ BP, corresponds to Heian Transgression and Nara-Heian-Kamakura warm stage of Japan (Private Communication from Sakaguchi and Olsen). Dunes, correlated with Kurosuna beds $\mathrm{K}_{4}$, formed during Little Ice Age regression $(290 \pm 60$ yrs BP, GIN-7870), corresponded to Edo regression in Japan (Taira, 1980a ; Sakaguchi, 1983). Dark-coniferous forests with some birch occupied almost all territory of the island. The climate and landscapes were similar to the present.

It is supposed, that active tectonic uplift with rate of $2.5-2.8 \mathrm{~mm} / \mathrm{y}$ of the islands began in Low Pleistocene and continues to present days (Melekestsev et al., 1974). Our data of the low marine terrace study contradict traditional opinion about active tectonic uplift of Kurile Islands in the Holocene (Kulakov, 1973 ; Melekestev et al., 1974 etc.) and another opinion, supposed, that uplift of the island changed to tectonic downlift within local plats with rate $2 \mathrm{~mm} / \mathrm{y}$ during second half of the Holocene (Bulgakov, 1994). The high marine terrace sequence (elevation to $100 \mathrm{~m}$ ) shows that the island area developed under intensive tectonic rise with rate of $0.8-0.9 \mathrm{~mm} / \mathrm{y}$ during Middle Pleistocene. It was supposed that Holocene marine terrace include terrace sequence of $18^{-}$ $20 \mathrm{~m}$ elevation. But correlation of marine 
deposits top in the studied terrace sections shows, that the terraces correspond to oceanlevel fluctuations of small magnitude of Holocene transgression and indicate their weak tectonic deformation.

\section{Acknowledgements}

We would like to thank L. P. Karaulova for providing pollen analysis. We are grateful to Director of Kurile Reserve M. B. Dikhan and his colleges for help during field work. The work was supported by grant "Terrace Sequence of Far East Island Territories of the Russia" N 93-05-14168 of the Russian Fond of Fundamental Investigations.

\section{References}

Arai, F., Machida, H., Okumura, K., Miyauchi, T., Soda, T. and Yamagata, K. (1986) Catalog for Late Quaternary marker-tephras in Japan II tephras occurring in Northeast Honshu and Hokkaido. Geograph. Rep. of Tokyo Metropolitan Univ., 21: 223-250

Bulgakov, R. F. (1993) New data about Quaternary history of southern islands of Kurile Ridge. Preprint by Vestnic of Moscow State University, Geographical Series, Dep. VINITI, 2490-B93: 21

Bulgakov, F. F. (1994) History of development of southern islands of Kurile Ridge. Referat of dissertation, Moscow: 20

Endo, K. and Uesugi, Y. (1972) Geomorphology and geology of the Tokoro coastal plain along the Sea of Okhotsk. Tokoro, 493-504

Grabkov, V.K., Berzan, A.P. and Alekseeva, L.M. (1989) Distribution of vegetation in southern part of Kunashiri Island. Preprint by Vestnic of Moscow State University, Geogragbical Series, Dep. VINITI, 2209-B89: 39

Jouze, A.P. (1962) Stratigraphical and paleogeographical investigations in North-Western part of Pacific Ocean. 258, Moscow : USSR Academy of Sciemces Publication

Korotky, A. M. and Khudyakov, G. I. (1990) Exogenic geomorphological systems of marine coasts. 216p, Nauka

Korotky, A. M., Grebennikova, T. A., Pushkar, V. S., Razjigaeva, N. G., Volkov, V. G., Ganzey, L. A., Mokhova, L. M., Bazarova, V. B., Makarova, T.R. (1994) Late Cenozoic climatic changes in south far east territory (Miocene-Pleistocne). Preprint by Vestnic of Moscow State University, Geogragbical Series,
Dep. VINITI, 1149-B94: 79

Kulakov, A. P. (1973) Quaternary coastal lines of Okbotsk and Japan Seas. 188p, Nauka

Machida, H. and Arai, F. (1992) Atlas of tephra in and around Japan. 276p, Unive. of Tokyo Press

Melekestsev, I. V., Braitseva, O. A., Erlikh, E. N., Shantser, A. E., Chelebaeva, A. I., Lupikina, E.G., Egorova, I. A. and Kozhemyaka, N. N.(1974) Kamchatka, Kurile and Komandar Islands. History of development of relief of Siberia and far east. 439p, Nauka

Ota, Y., Matsushima, Y. and Moriwaki, H. (1982) Notes on the Holocene sea-level study in Japan On the basis of "Atlas of Holocene sea-level records in Japan”. The Quat. Res. (Japan), 21 : 133143

Polunin, G.V. (1969) About absolute age of high terrace and Mendeleeva Volcano on Kunashiri Island. Bull. of Volcanological Stations, Siberian Branch of USSR Academy of Sciences, N 45

Pryalukhina, A. F.(1964) About Quaternary sedimentary deposits of Kurile Islands. Reports of Sakbalin Complex Scientific Research Institute, Vol. 8

Sakaguchi, Y. (1983) Warm and cold stages in the past 7600 years in Japan and their global correlation. Bull. of the Department of Geography University of Tokyo, 15: 1-31

Sakaguchi, Y., Kashima, K. and Matsubara, A. (1985) Holocene marine deposits in Hokkaido and their sedimentary environments. Bull. of the Department of Geography University of Tokyo, 17: 1-17

Sakaguchi, Y. and Okumura, K. (1986) Interglacial climates and relict red soils in northern Japan based on pollen records of Interglacial deposits in Eastern Hokkaido. Bull. of the Department of Geography University of Tokyo, 18: 29-48

Schofield, J. C.(1964) Postglacial sea level and isostatic uplift. New Zealand Jour. Geol. Geogphys., 7 : 359-370

Taira, K. (1980a) Holocene events in Japan: Paleooceanology, volcanism and relative sea-level oscillations. Palaeogeography, Palaeoclimatology, Palaeoecology, $32: 69-77$

Taira, K. (1980b) Radiocarbon dating of shell middens and Holocene sea-level fluctuations in Japan. Palaeogeography, Palaeoclimatology, Palaeoecology, 32 : 79-87

Taira, K. (1992) Holocene paleoceanographic changes in Japan. Reports of the Taisetsuzan. Institute of Science, 4 (27) : 1-7

Yonekura, N. (1982) Mobile islands in the Pacific Ocean-Comparative studies on their late Quaternary neotectonics. Kagaku, 52: 575-583 


\section{千島列島国後島の完新世海成段丘群}

A. M. コロッツキー*1・N. G. ラジィガエバ*1・T. A. グレベンニコワ*1・

L. A. ガンゼイ*1・L． M. モコーバ*1・V． B. バザロワ*1・

L. D. スルグルチスキー*2

\section{要 旨}

アトランチック,サブボレアル, サブアトランチッ ク段丘を含む国後島の低位海成段丘群は，中・後期 完新世の海水準変動を反映している. 比高 5〜 6m の アトランチック段丘はストームリッジ堆積物からな ク，湖成シルト層とピート層に覆われる。

この段丘の形成期は, 花粉分析や珪藻分析, ${ }^{14} \mathrm{C}$ 年 代測定 $(5,450 \sim 6,070$ yrs BP ) によって完新世オプ ティマムに比定される. この時期の初頭には, 海水 準は $25 \mathrm{~m}$ 程度低下しており, 北国後陸橋は繫がって いたが, その後の急激な海面上昇によって切断され た. 海面上昇は最高 $+2.5 \sim 3 \mathrm{~m}$ に達し, 太平洋側に広 い湾が形成され, 南千島地峡のオホーツク海側には 大きな潟が出現した.このため, 岸辺では急激な削 剝が進行し, 沖合に巨大なバリアーが形成された. 植 生は, 現在より温暖な針葉樹広葉樹混淆林であった。

アトランチックーサブボレアル移行期には，小規 模な海退があり, 汀線内の河川沿いには比高 $20 \mathrm{~m}$ 程 度の砂丘が形成された。 セルノボドスキ一地峡とク ルグロブスキ一地峡には小規模な陸橋が再現した。 サブボレアル期の比高 $2.5 \mathrm{~m}$ の段丘堆積物からは, $4,010 \sim 3,400$ yrs BP と2,950〜2,620 yrs BP の 2 回の 小海進が認められる。この海進によって前期に形成 された砂丘は侵食され，中南部の海岸沿いに再び小 規模な湾と潟が出現した.この時期の植生は現在よ クやや温暖な，わずかに広葉樹の混じる針葉樹林で ある. サブボレアルーサブアトランチック移行期 (2,220〜 1,170 yrs BP) には寒冷期の到来とともに, 海退が進行し，砂丘や沼沢地が形成された。サブア トランチック期（1,170～820 yrs BP） には比高 $2.5 \mathrm{~m}$ の段丘が形成された。 この時期の海水準は約 $+1 \mathrm{~m}$ であった. その後, 小水期に入り, 現在の砂丘の形 成が行われた。

*1 ロシア科学アカデミ一極東支所太平洋地理学研究所

*2 ロシア科学アカデミー地質学研究所
これらの海成段丘の形成過程から，この地域では 少なくとも完新世後半以降, 顕著な構造運動は認め られないことが明らかになった。

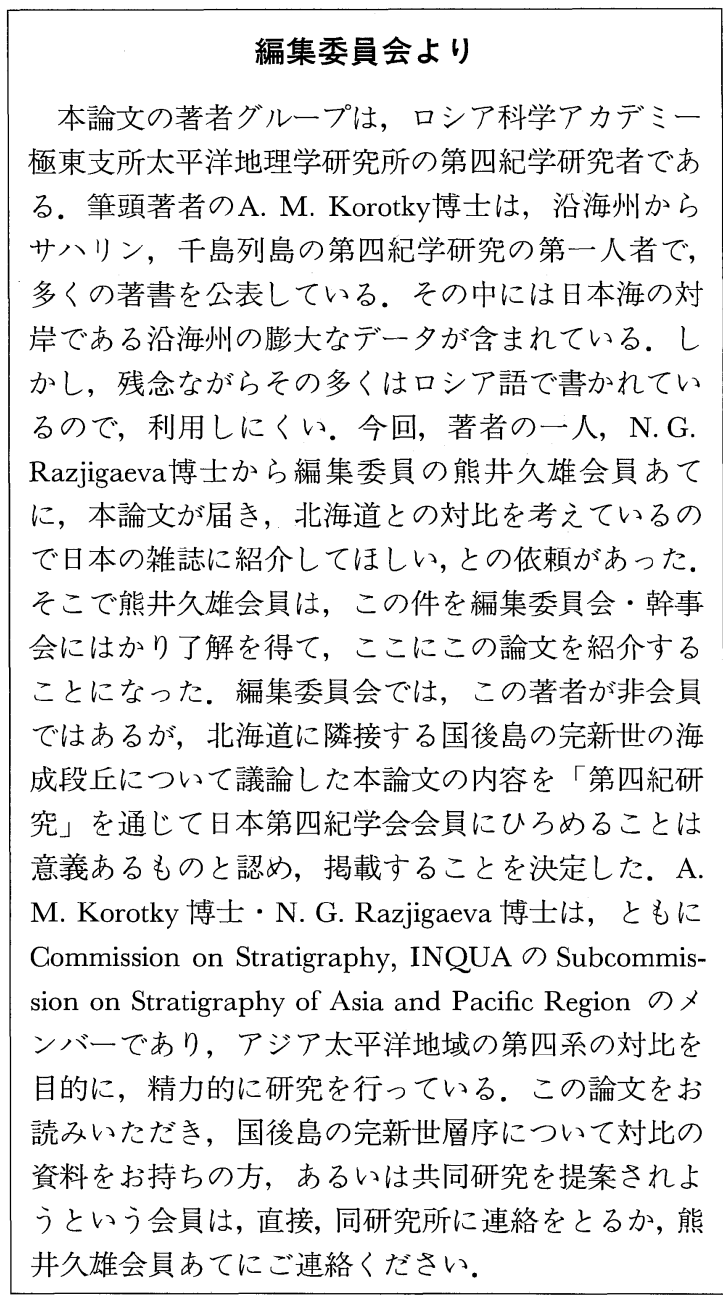

